\title{
Brown Trout Redd Locations in the Northernmost Section of Spearfish Creek in Spearfish, South Dakota, USA
}

\author{
Michael J. Robidoux ${ }^{1}$, Jill M. Voorhees ${ }^{1 *}$, Abigail Domagall'2, Michael E. Barnes ${ }^{1}$ \\ ${ }^{1}$ South Dakota Department of Game, Fish and Parks, McNenny State Fish Hatchery, Spearfish, South Dakota, USA \\ ${ }^{2}$ School of Natural Sciences, Environmental Physical Science, Black Hills State University, Spearfish, South Dakota, USA \\ Email: ^jill.voorhees@state.sd.us
}

How to cite this paper: Robidoux, M.J., Voorhees, J.M., Domagall, A. and Barnes, M.E. (2022) Brown Trout Redd Locations in the Northernmost Section of Spearfish Creek in Spearfish, South Dakota, USA.

Natural Resources, 13, 1-15.

https://doi.org/10.4236/nr.2022.131001

Received: December 12, 2022

Accepted: January 22, 2022

Published: January 25, 2022

Copyright $\odot 2022$ by author(s) and Scientific Research Publishing Inc. This work is licensed under the Creative Commons Attribution International License (CC BY 4.0).

http://creativecommons.org/licenses/by/4.0/

\begin{abstract}
Salmonid fish are known to reproduce throughout the Black Hills in South Dakota, however, it is not known when or where they are spawning or how successful their spawning is. This study documented for the first-time brown trout (Salmo trutta) redd locations and redd construction timing in a $1.6 \mathrm{~km}$ reach of Spearfish Creek, within the northern most part of the city of Spearfish, South Dakota, USA in 2020. Redds were first observed on October 13, 2020, with observations continuing until November 17 when no new redds were spotted. Redd construction peaked during the first week of November, with 52 observed. A total of 146 redds was recorded over the course of the study, resulting in a density of $91 \mathrm{redds} / \mathrm{km}$. This is the first study to document redds in this section of Spearfish Creek. These observations will allow for comparisons to future spawning activity which may be impacted by the increased urbanization likely along this section of the creek. Hopefully, This study can also guide future research and habitat projects throughout this section of Spearfish Creek, and potentially throughout this region.
\end{abstract}

\section{Keywords}

Brown Trout, Redds, Spawning, Spearfish, South Dakota

\section{Introduction}

Brown trout (Salmo trutta) were introduced into the Black Hills of South Dakota, the USA in 1890 and quickly became naturalized [1]. With self-sustaining populations in nearly all $1287 \mathrm{~km}$ of streams in the Black Hills with the suitable habitat, they are an extremely important recreational fish species [2] [3] [4]. Black Hills brown trout populations are maintained entirely by natural repro- 
duction; no hatchery stocking of brown trout occurs [3].

Brown trout typically spawn in the northern hemisphere during the fall [5] [6]. Spawning in the Black Hills typically begins in mid-October and continues until the middle of November [7] [8] [9]. Similar to other salmonids, female brown trout make gravel pit nests called redds for egg deposition [10]. The location of redds within a stream is based on stream morphology, substrates, and water velocity [11], with higher water velocities flowing over course substrates at shallower water depths preferred [5] [9] [12]. The number of redds in a stream section has been used to monitor trout populations [13] [14] [15] [16] [17], particularly in response to changes in water flow and temperature [18].

The city of Spearfish in the northern Black Hills contains a section of Spearfish Creek with an abundant brown trout population [19]. Future creek flows may be impacted by the growing human population of Spearfish, and the entire northern Black Hills [20]. Changes in Spearfish Creek flows and temperatures may also be impacted by future agricultural and commercial demands, such as changes in discharge from the D. C. Booth Historic National Fish Hatchery [21] [22]. Thus, information is needed on the current status of brown trout reproduction to create a baseline for comparison in the future as environmental conditions change.

Martling et al. [9] described redd numbers in a southern reach of Spearfish Creek in the city of Spearfish. However, no information on redd locations or numbers in Spearfish Creek exists beyond the relatively small section that Martling et al. [9] sampled. Thus, the objective of this study was to survey redds in a reach of Spearfish Creek on the northern edge of Spearfish. With the information from this study and other similar studies, management staff can begin to glean where habitat projects should occur and where money can be spent to improve overall spawning and recruitment to improve angler satisfaction even further.

\section{Methods and Materials}

\subsection{Study Area}

Spearfish Creek is located in the northern Black Hills, Lawrence County, South Dakota, USA. The creek has an upper section that begins at the headwaters and flows northward downstream through Spearfish Canyon. This upper section ends towards the bottom of the canyon where most of the water enters an aqueduct. After the aqueduct intake, the creek is dry for most of the year. Water re-enters the creek channel after its discharge from the hydroelectric plant, resulting in continuous flows of the creek through the city of Spearfish. This lower section eventually discharges into the Redwater River. Spearfish Creek at the city of Spearfish flows ranged from $1.38 \mathrm{~m}^{3} / \mathrm{s}$ to $2.16 \mathrm{~m}^{3} / \mathrm{s}$ during the duration of this study [23].

This study occurred in a $1.67 \mathrm{~km}$ long mainstem reach of Spearfish Creek within the city of Spearfish (Figure 1). The study site was bordered upstream by 


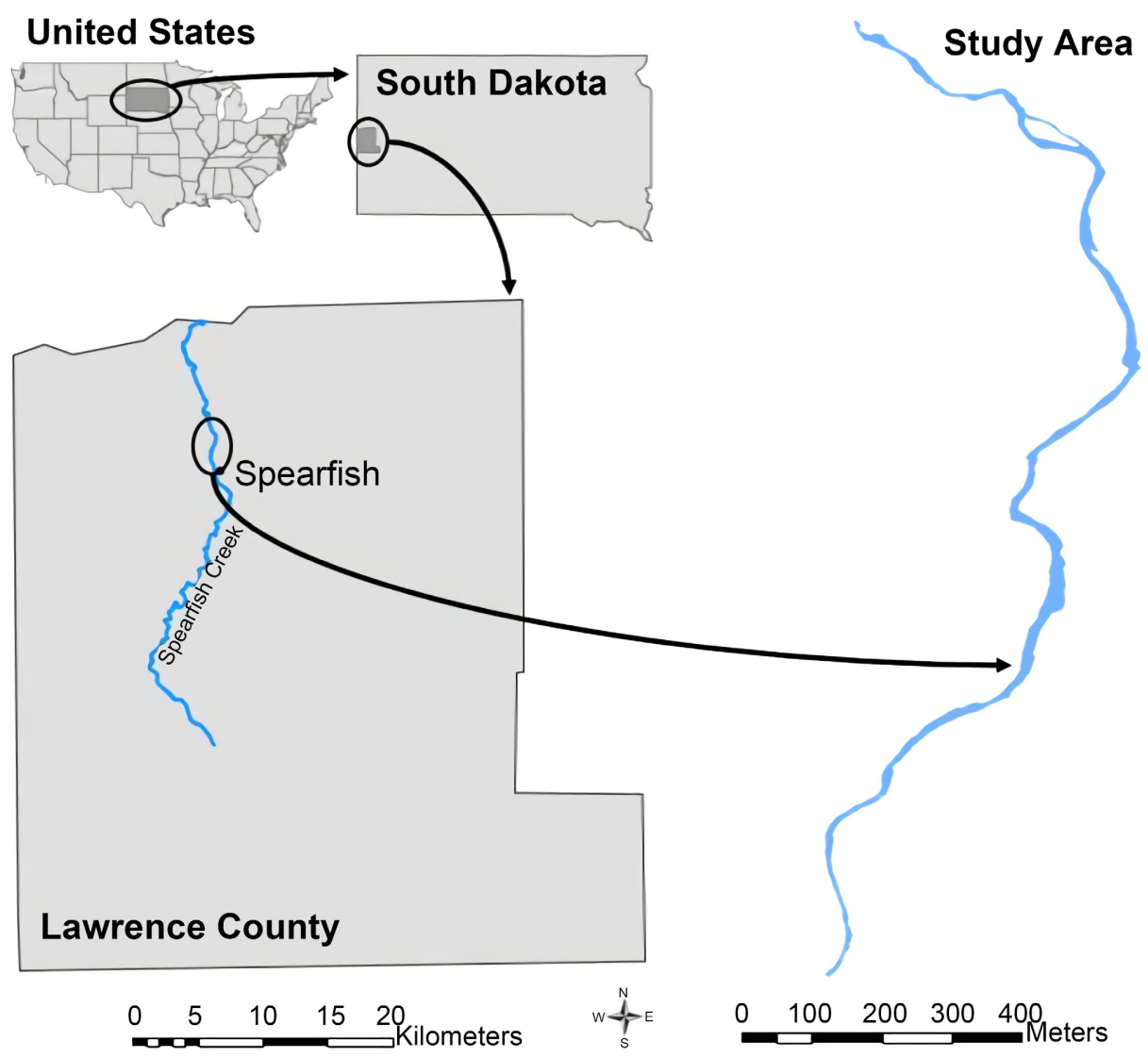

Figure 1. Location of Spearfish Creek and the creek reach surveyed.

the Jorgensen Park walking path bridge $\left(44^{\circ} 30^{\prime} 21.19^{\prime \prime} \mathrm{N},-103^{\circ} 51^{\prime} 59.05^{\prime \prime} \mathrm{W}\right)$ and downstream by the bridge at Highway $14\left(44^{\circ} 31^{\prime} 4.73^{\prime \prime} \mathrm{N},-103^{\circ} 51^{\prime} 56.68^{\prime \prime} \mathrm{W}\right)$. The distance from the hydroelectric plant $\left(44^{\circ} 28^{\prime} 4.73^{\prime \prime} \mathrm{N},-103^{\circ} 51^{\prime} 56.68^{\prime \prime} \mathrm{W}\right)$ to the start of the survey site is approximately $3.86 \mathrm{~km}$. Martling et al. [9] surveyed trout redds in a section of Spearfish Creek in short reach beginning at the hydroelectric plant. The study site of the current study was approximately $2.92 \mathrm{~km}$ from the end of the Martling et al. [9] survey location $\left(44^{\circ} 29^{\prime} 2.47^{\prime \prime} \mathrm{N},-103^{\circ} 51^{\prime} 44.06^{\prime \prime} \mathrm{W}\right)$ (Figure 2). The study reach was divided into five similarly-sized sections (Figure 3).

Land use in the study area varied. In the survey reach, the riparian area furthest upstream was a developed city park. Immediately downstream, the creek flows through an area of residential housing (Figure 4). The final part of the survey area was primarily undeveloped park land and a small area of commercial development (Figure 5).

Calcite precipitate characterizes the substrate of Spearfish Creek [19]. The creek has a wide variety of substrate sizes and in-stream habitats [9]. While Spearfish Creek contains naturalized populations of brown trout, rainbow trout (Oncorhynchus mykiss), and brook trout (Salvelinus fontinalis), the fish population in the creek section in this study consisted almost exclusively of brown trout [24]. 
Spearfish Creek in Spearfish City Limits

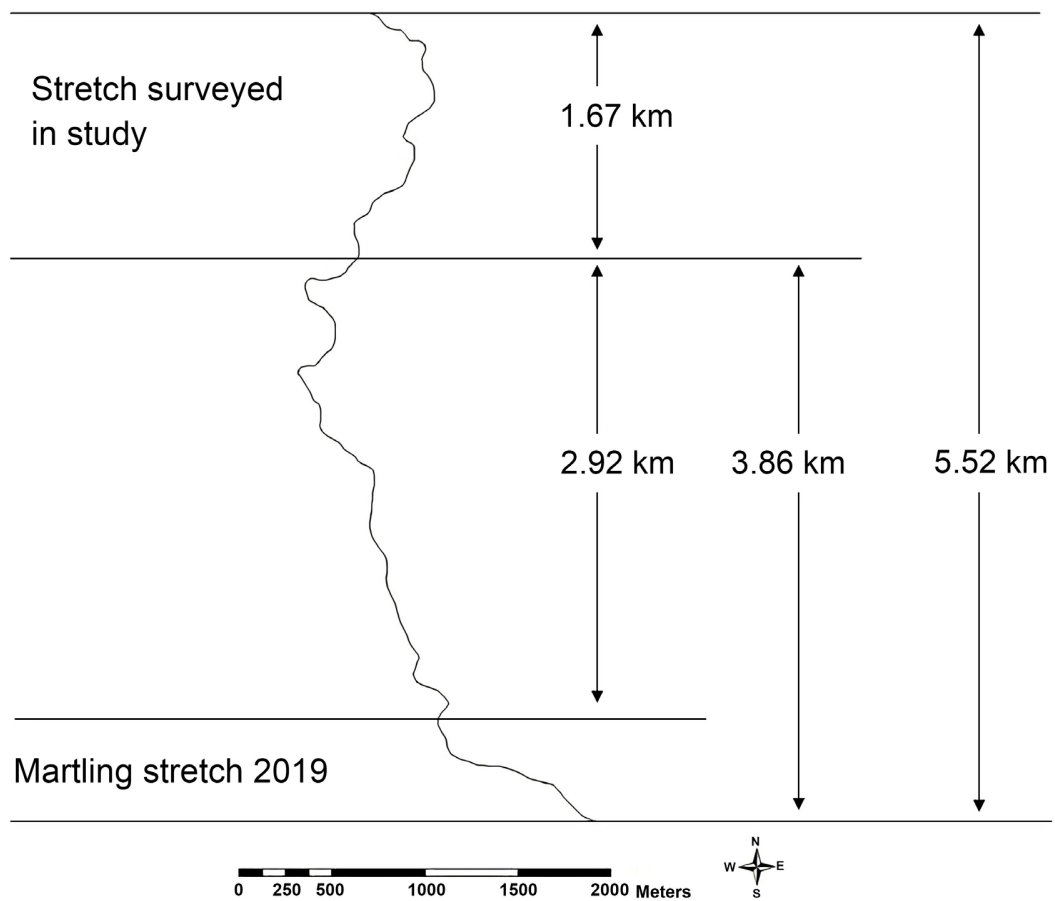

Figure 2. Location and distances of survey site, Marling et al. [9] study site, and hydropower plant.

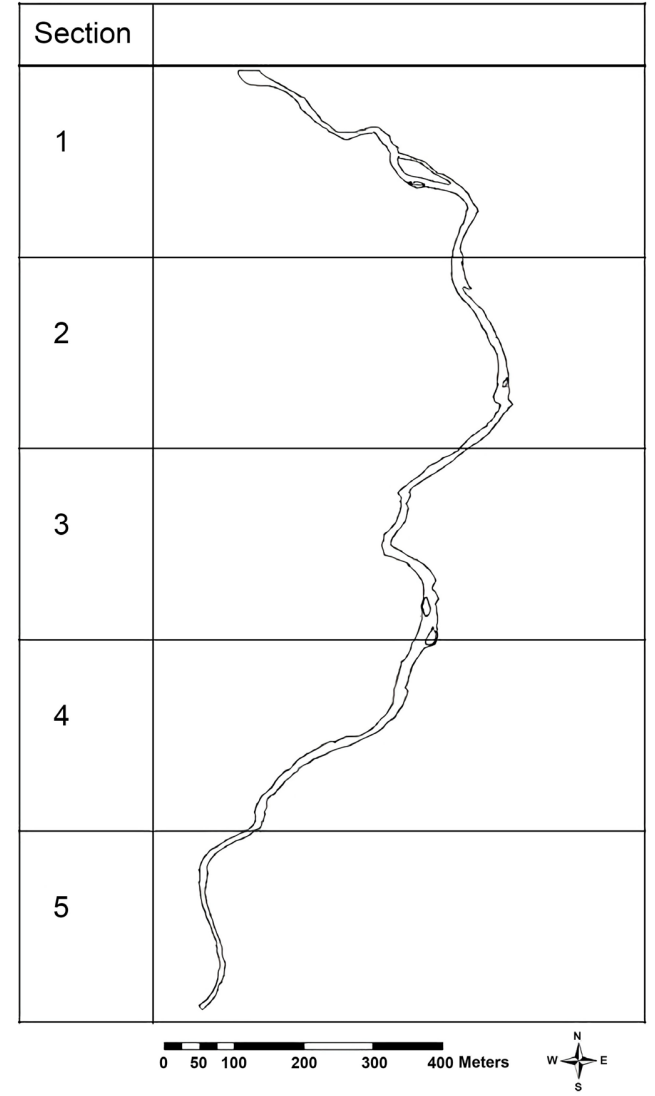

Figure 3. Study area divided into five sections (section 5 is the furthest upstream). 


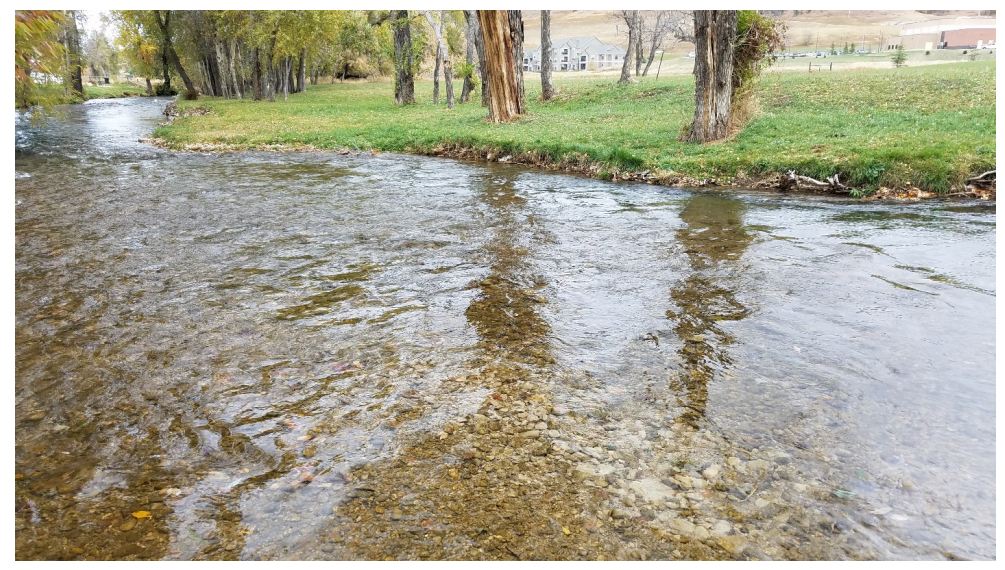

Figure 4. Photo of residential section of Spearfish Creek.

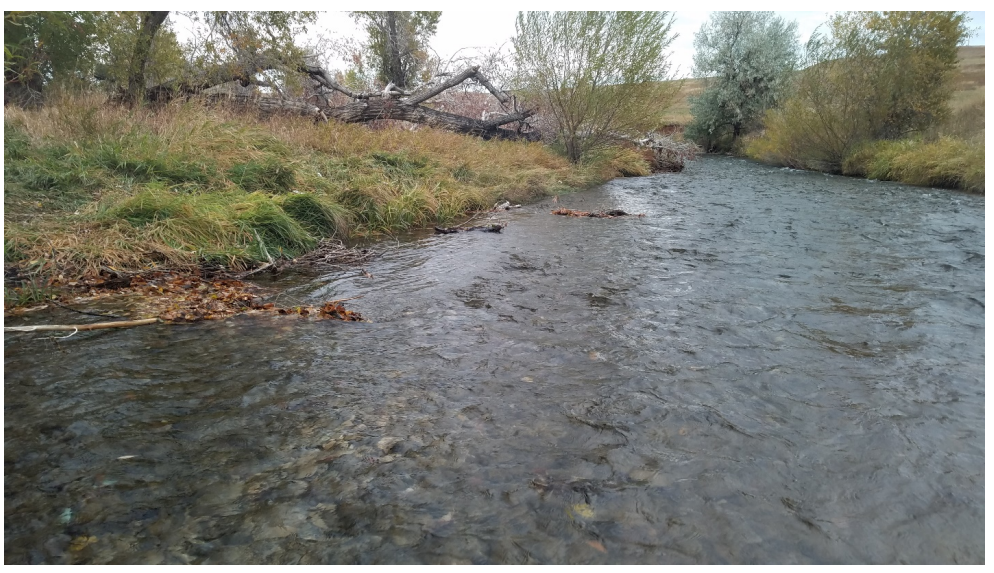

Figure 5. Photo of undeveloped park land of Spearfish Creek.

\subsection{Redd Identification and Location}

Redd sampling began on October 13,2020. Observations occurred approximately weekly until the construction of new redds and observations of spawning fish had ceased, as described by Gallagher et al. [25]. Each weekly survey lasted approximately two to three hours, depending on the number of redds observed. The final sampling date was November 17, 2020. Redd identification followed the techniques described previously [7] [8] [9] [25]. However, because redds varied greatly in size, and creek conditions varied from week-to-week, a redd was loosely defined as the presence of a clear pit and overturned substrate that formed a mound and/or a clear tail (Figure 6) [26]. Redd locations were recorded using TerraSync on the Trimble Geo7X Global Position System (Sunnyvale, California, USA). Every redd observed each week was marked, even if it was a repeat of prior weeks.

Ambient air temperatures were obtained for each of the sampling dates from a commercial website

(https://www.wunderground.com/history/daily/us/sd/spearfish). The amount of daylight for each date was also recorded

(https://sunrise-sunset.org/us/spearfish-sd/2020/11). 


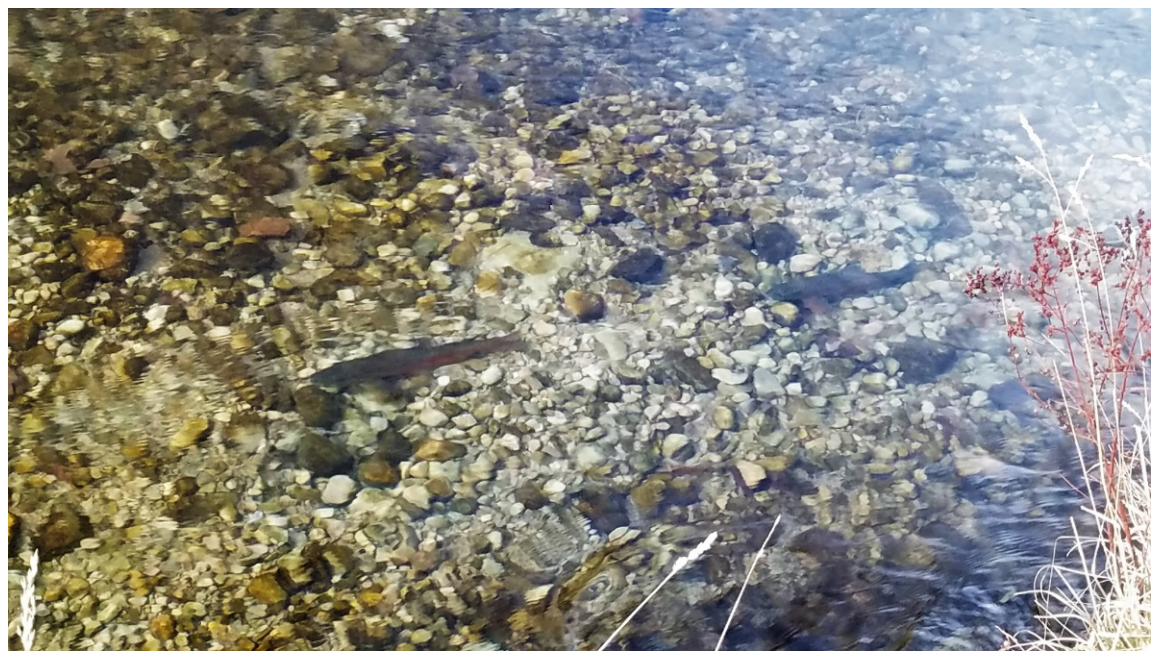

Figure 6. Photo of brown trout in study area on a typical redd.

\section{Results}

A total of 146 redds were observed over the six-week study period. Redds were first observed on October 13 and redd construction ceased after November 17. Peak spawning activity was observed on November 3, when 52 new redds were observed (Table 1). Brown trout were the only fish species visually observed in the study area. During the fifth week of the study, redds started to deteriorate rapidly making it more difficult to observe those redds previously recorded. Redd construction varied considerably throughout the study area (Figures 7-11). A few creek sections in the study area had relatively high redd concentrations (Figures 12-14). Mean daily ambient air temperature varied greatly during the study, with temperatures dropping to $-10^{\circ} \mathrm{C}$ in one week of the study (Table 2). A sizable number of redds were observed under the Highway 14 bridge at the north end (section 1) of the study site (Figure 15).

\section{Discussion}

\subsection{Redd Timing}

The timing of redd construction in this study from October 13 to November 17 was similar to that reported elsewhere in the Black Hills. Martling et al. [9] observed the first redds in Spearfish Creek upstream from the current study site on October 15, with the final redds observed on November 12. Ketelsen et al. [7] reported that brown trout in Rapid Creek and Box Elder Creek began on October 14 and continued until November 5. Blaine et al. [8] observed the first brown trout redds in Crow Creek on October 17, with the final redds appearing on November 21. These spawning dates observed in this study are also within the range of dates reported elsewhere in the United States [5] [6] and Canada [27]. However, spawning of brown trout in the Black Hills is earlier than that reported for brown trout in their native range [28] [29], likely due to differences in latitude, photoperiod, altitude, and water temperatures [18] [26] [30] [31]. 
Table 1. The number of redds observed by week and cumulatively from a section of Spearfish Creek in the city of Spearfish, South Dakota, USA during the fall of 2020.

\begin{tabular}{ccc}
\hline Date & \multicolumn{2}{c}{ Redds } \\
\cline { 2 - 3 } & New & Cumulative \\
\hline October 13 & 14 & 14 \\
October 20 & 30 & 44 \\
October 30 & 22 & 66 \\
November 5 & 52 & 118 \\
November 10 & 24 & 142 \\
November 17 & 4 & 146 \\
\hline
\end{tabular}

Table 2. Ambient air temperature and daylight length on the days of sampling redds from a section of Spearfish Creek in the city of Spearfish, South Dakota, USA during the fall of 2020 .

\begin{tabular}{ccccc}
\hline \multirow{2}{*}{ Date } & \multicolumn{3}{c}{ Temperature $\left({ }^{\circ} \mathrm{C}\right)$} \\
\cline { 2 - 5 } & Minimum & Maximum & Mean & Daylight (hours) \\
\hline October 13 & 5.0 & 20.0 & 11.1 & 11.0 \\
October 20 & -1.1 & 6.1 & 2.2 & 10.4 \\
October 30 & 6.1 & 23.9 & 17.3 & 10 \\
November 5 & 1.1 & 20.0 & 12.0 & 9.6 \\
November 10 & -10.1 & 3.9 & -0.8 & 9.5 \\
November 17 & -1.1 & 18.9 & 9.9 & 9.3 \\
\hline
\end{tabular}

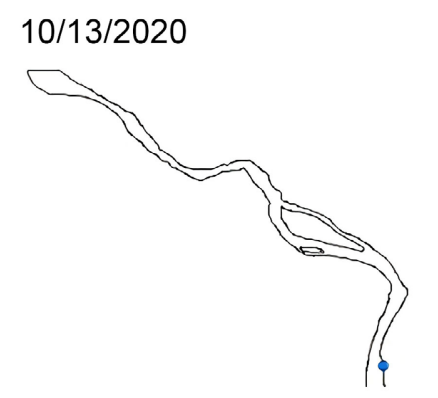

$10 / 20 / 2020$

$10 / 31 / 2020$

$11 / 5 / 2020$
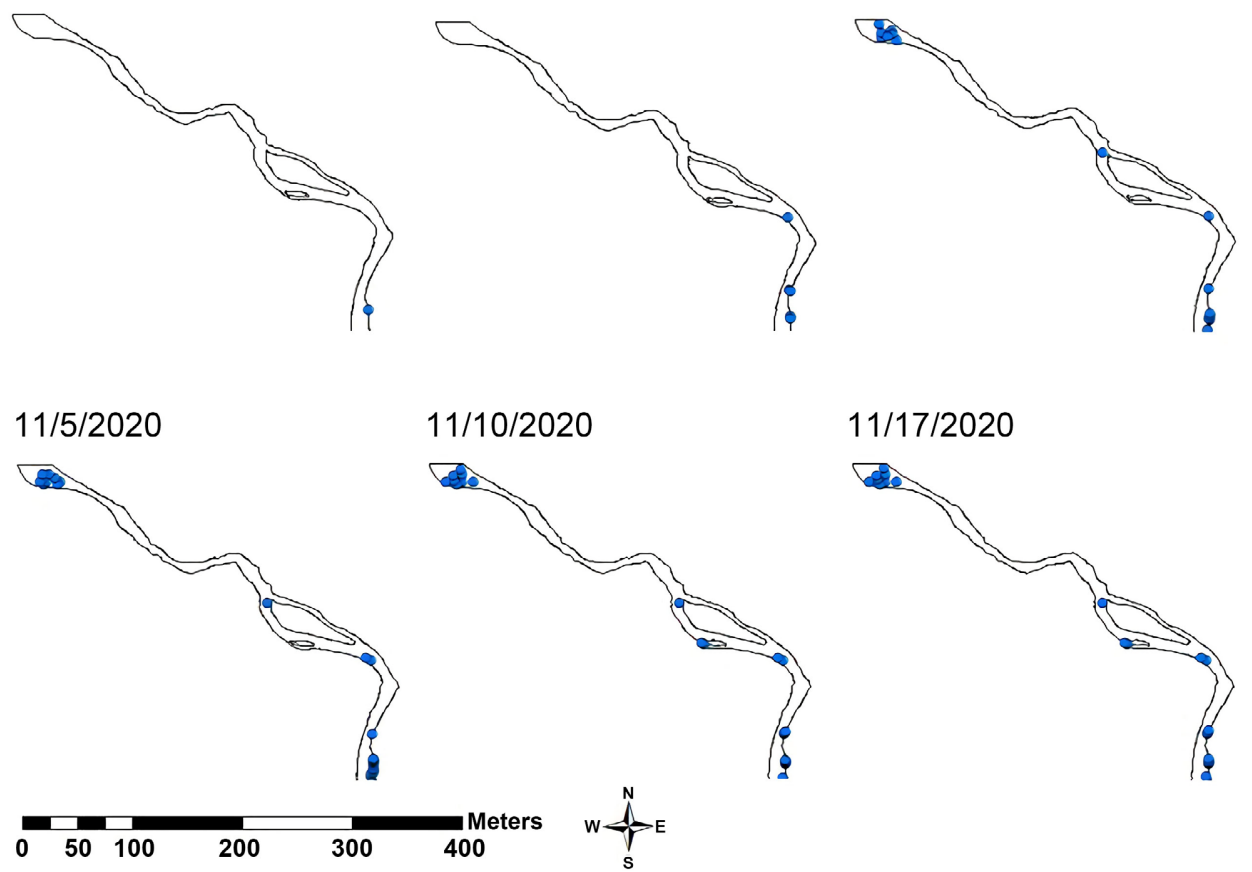

Figure 7. Weekly redd locations and numbers (as denoted by blue dots) in section 1 of Spearfish Creek study stretch. 


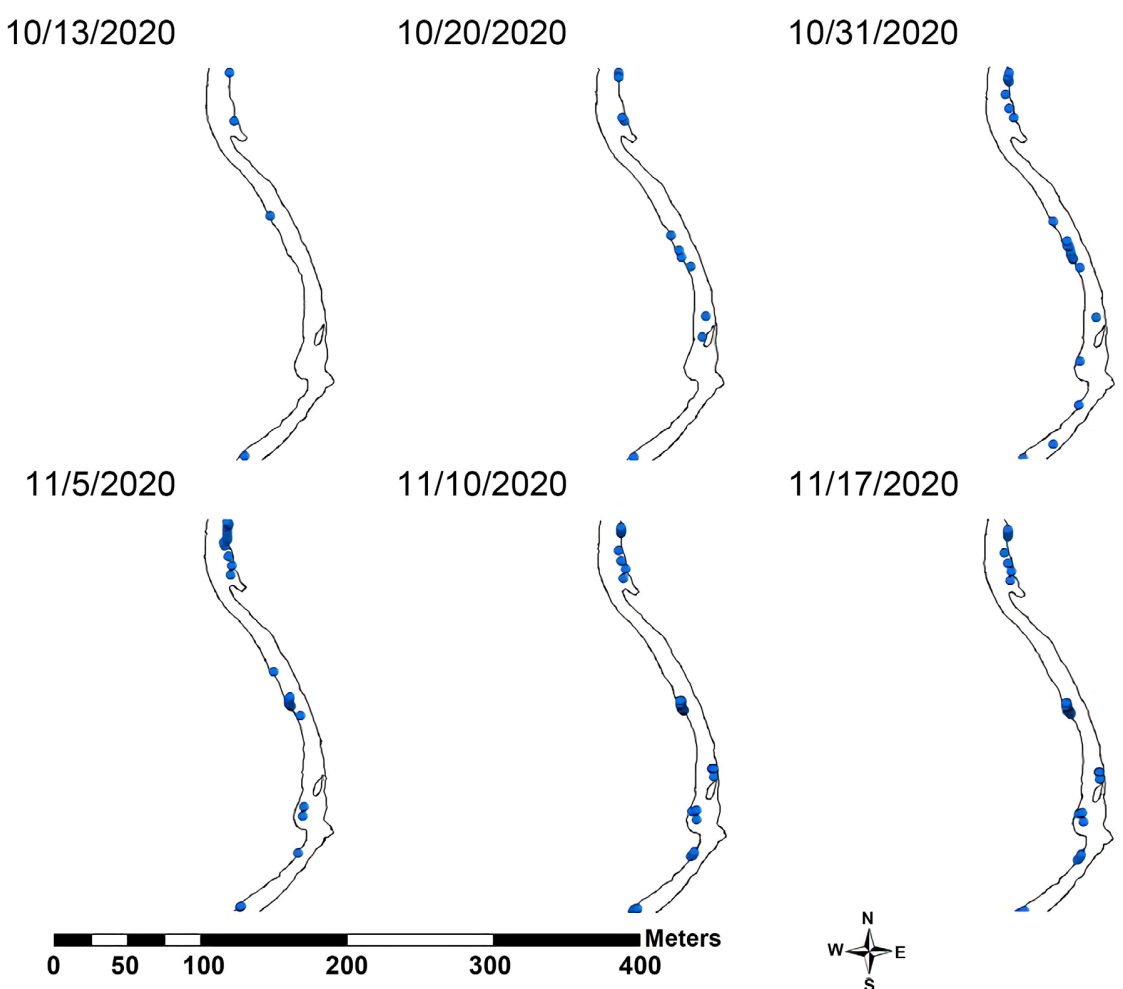

Figure 8. Weekly redd locations and numbers (as denoted by blue dots) in section 2 of Spearfish Creek study stretch.

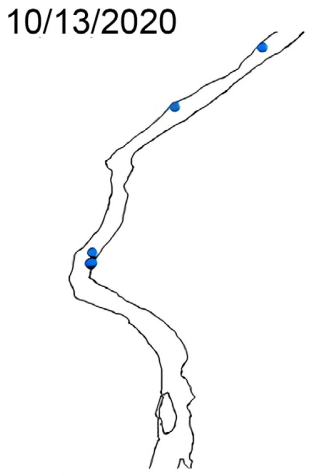

$11 / 5 / 2020$
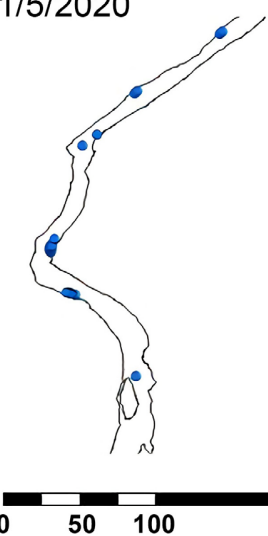

$10 / 20 / 2020$

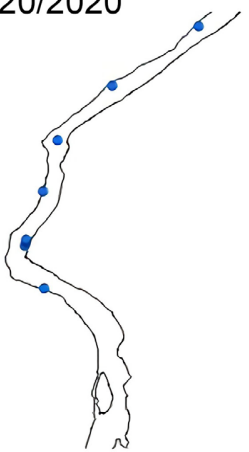

$11 / 10 / 2020$

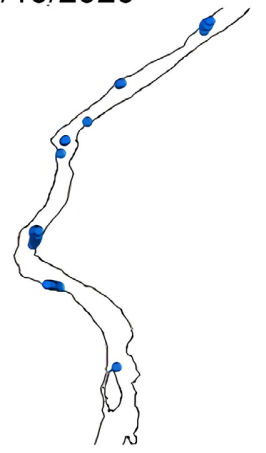

400

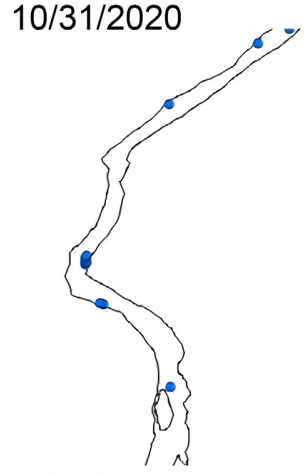

$11 / 17 / 2020$

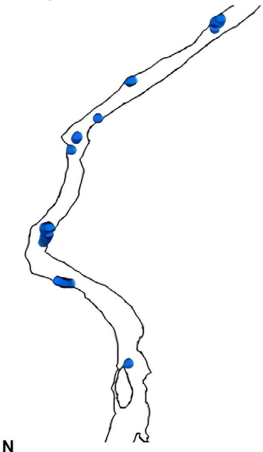

Figure 9. Weekly redd locations and numbers (as denoted by blue dots) in section 3 of Spearfish Creek study stretch. 


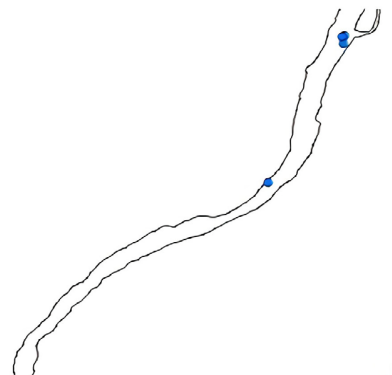

$11 / 5 / 2020$

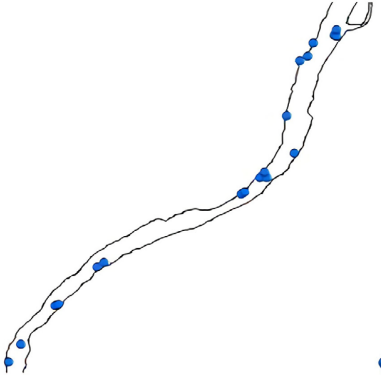

$11 / 10 / 2020$

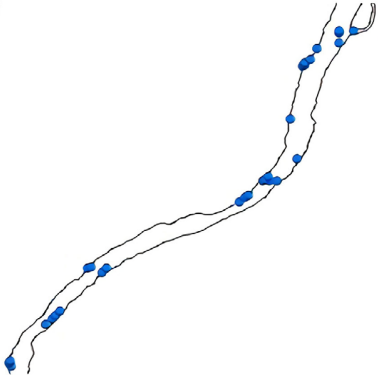

$11 / 17 / 2020$

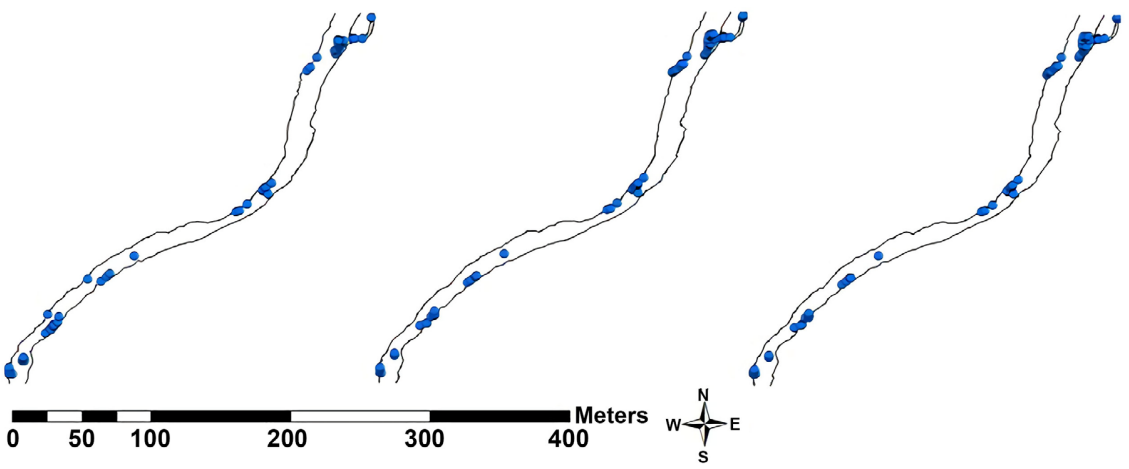

Figure 10. Weekly redd locations and numbers (as denoted by blue dots) in section 4 of Spearfish Creek study stretch.

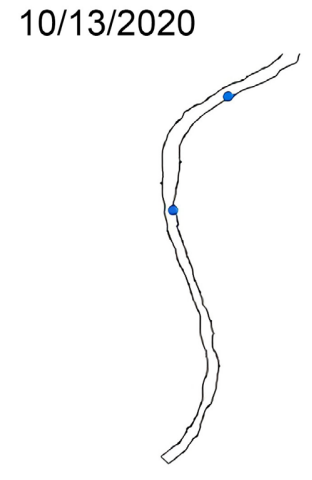

$11 / 5 / 2020$

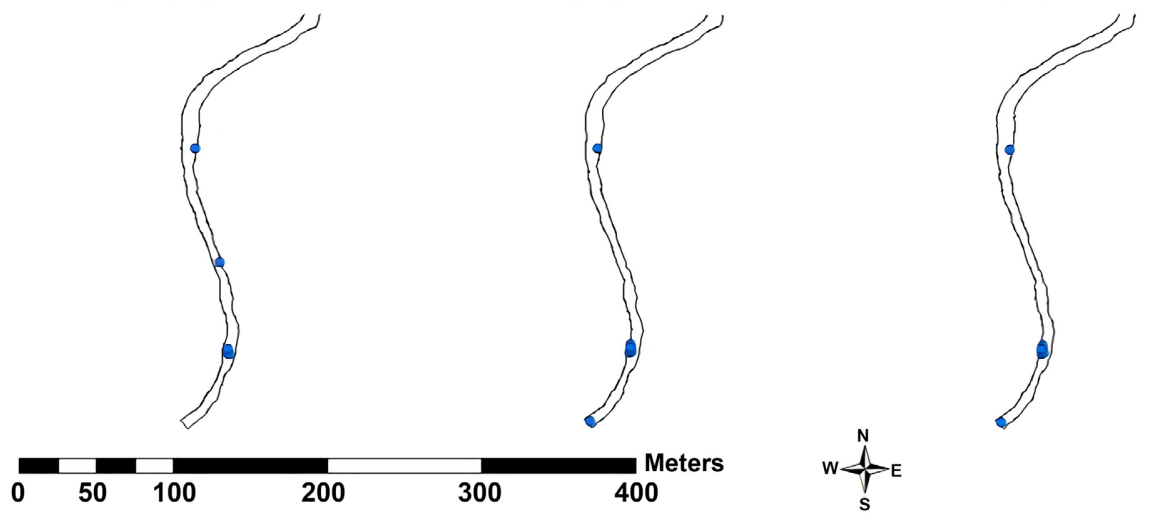

$10 / 20 / 2020$

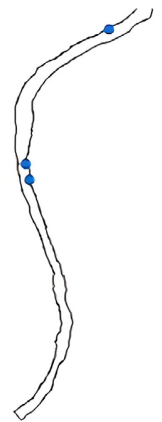

$11 / 10 / 2020$

400

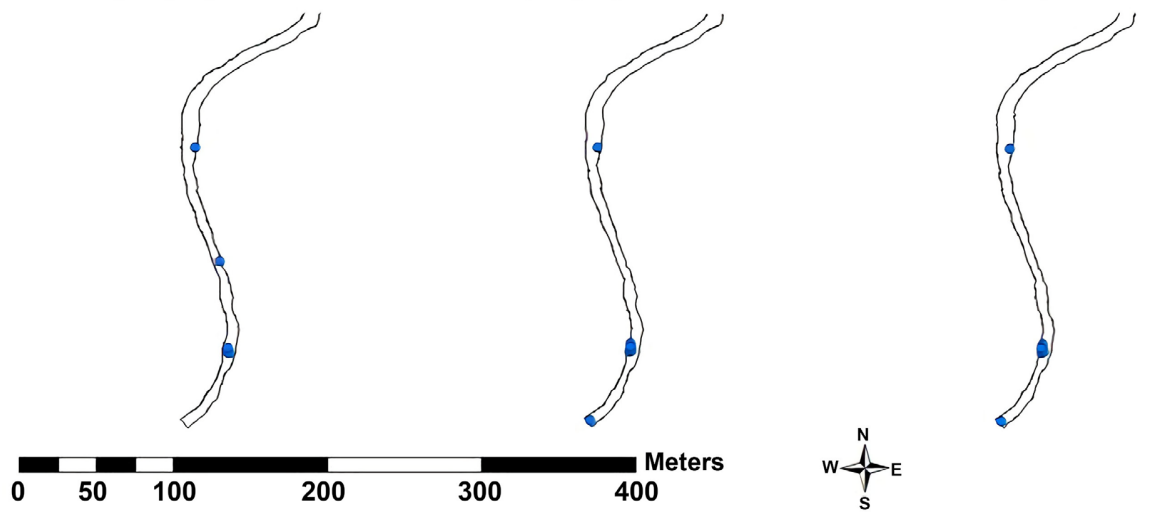

$10 / 31 / 2020$

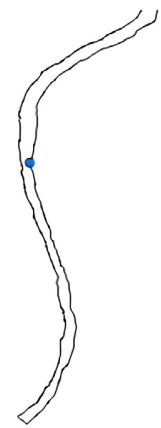

$11 / 17 / 2020$

Figure 11. Weekly redd locations and numbers (as denoted by blue dots) in section 5 of Spearfish Creek study stretch. 


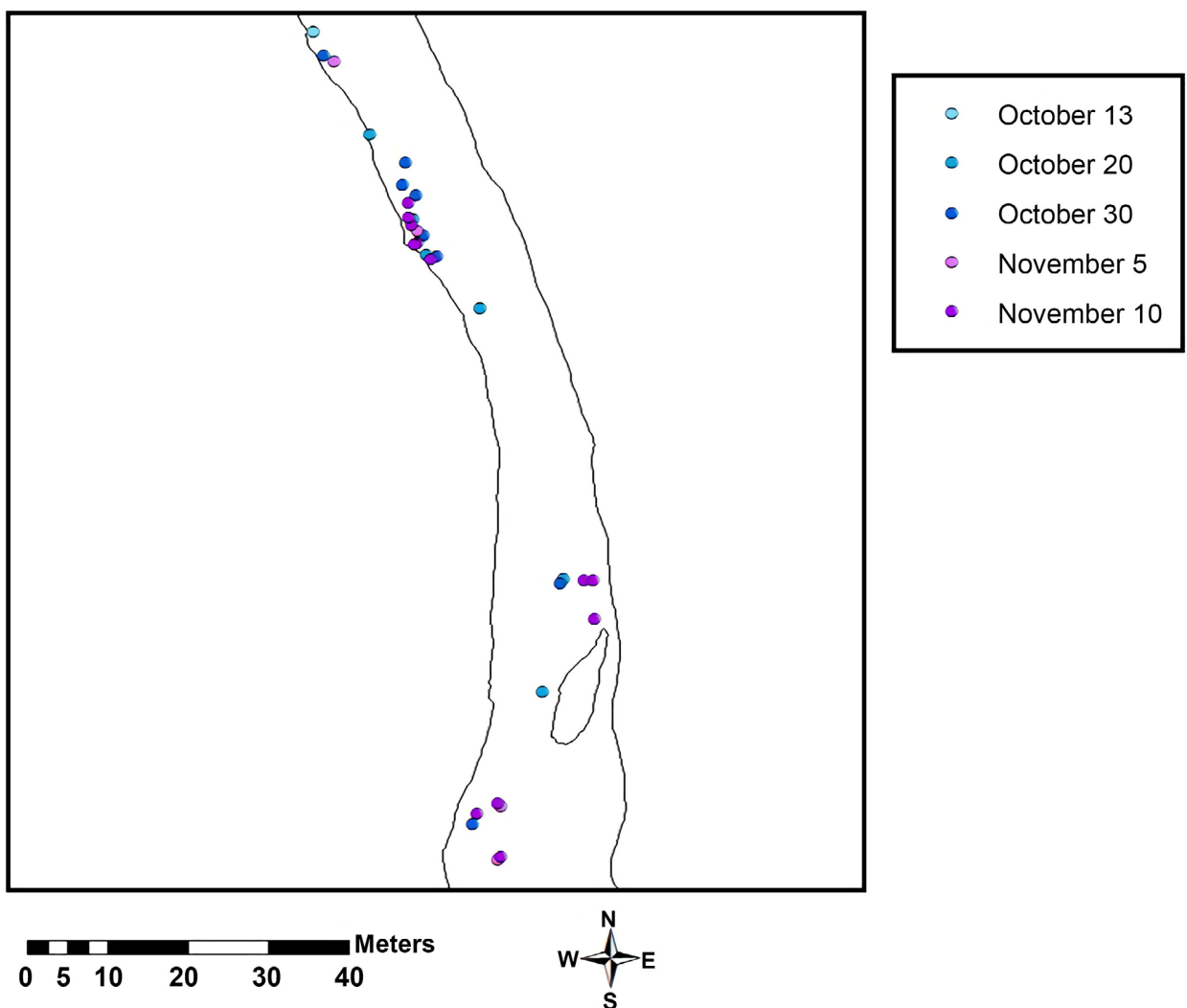

Figure 12. Weekly additions of redds in one concentrated area in section 2 .
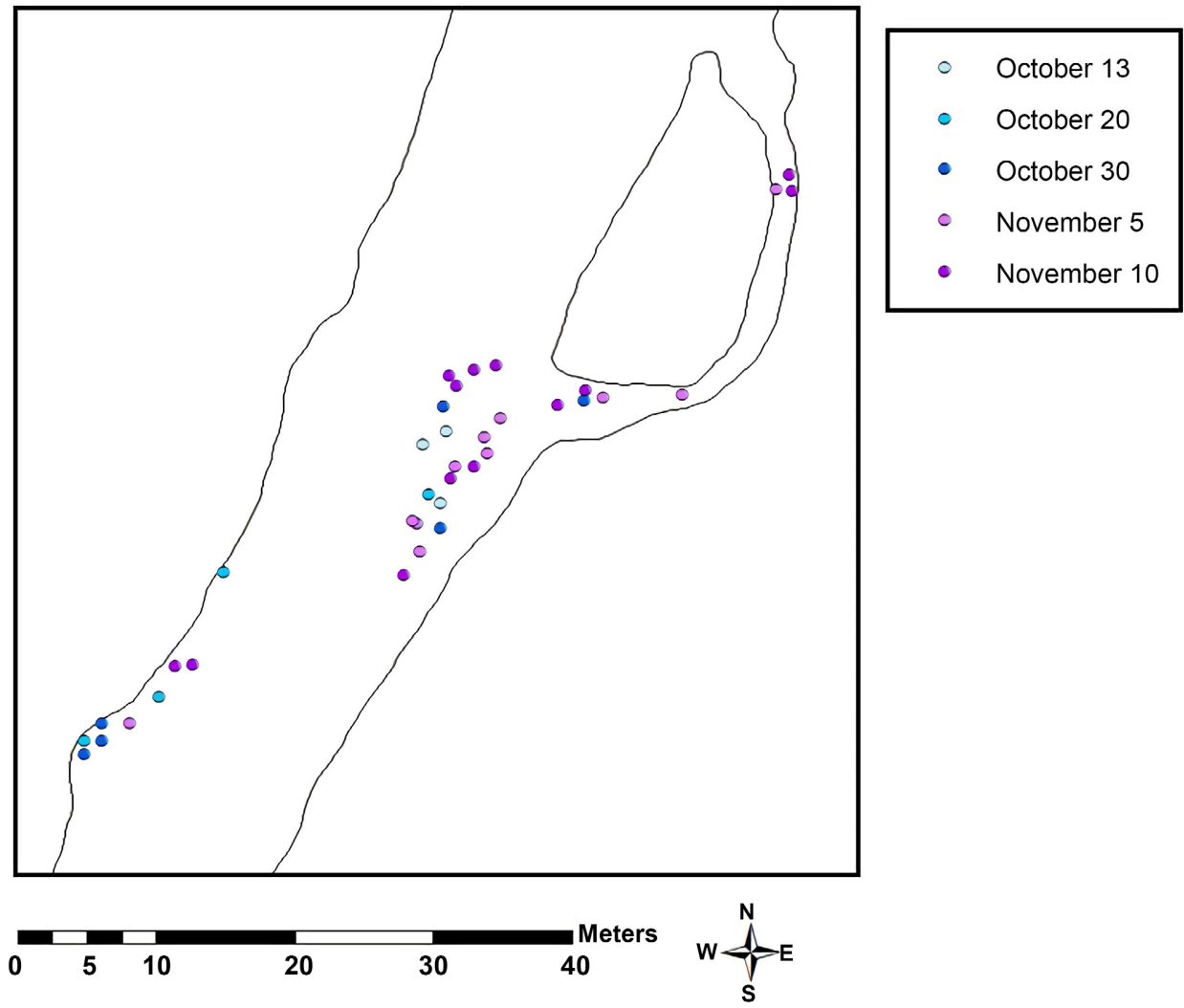

Figure 13. Weekly additions of redds in one concentrated area in section 4 . 


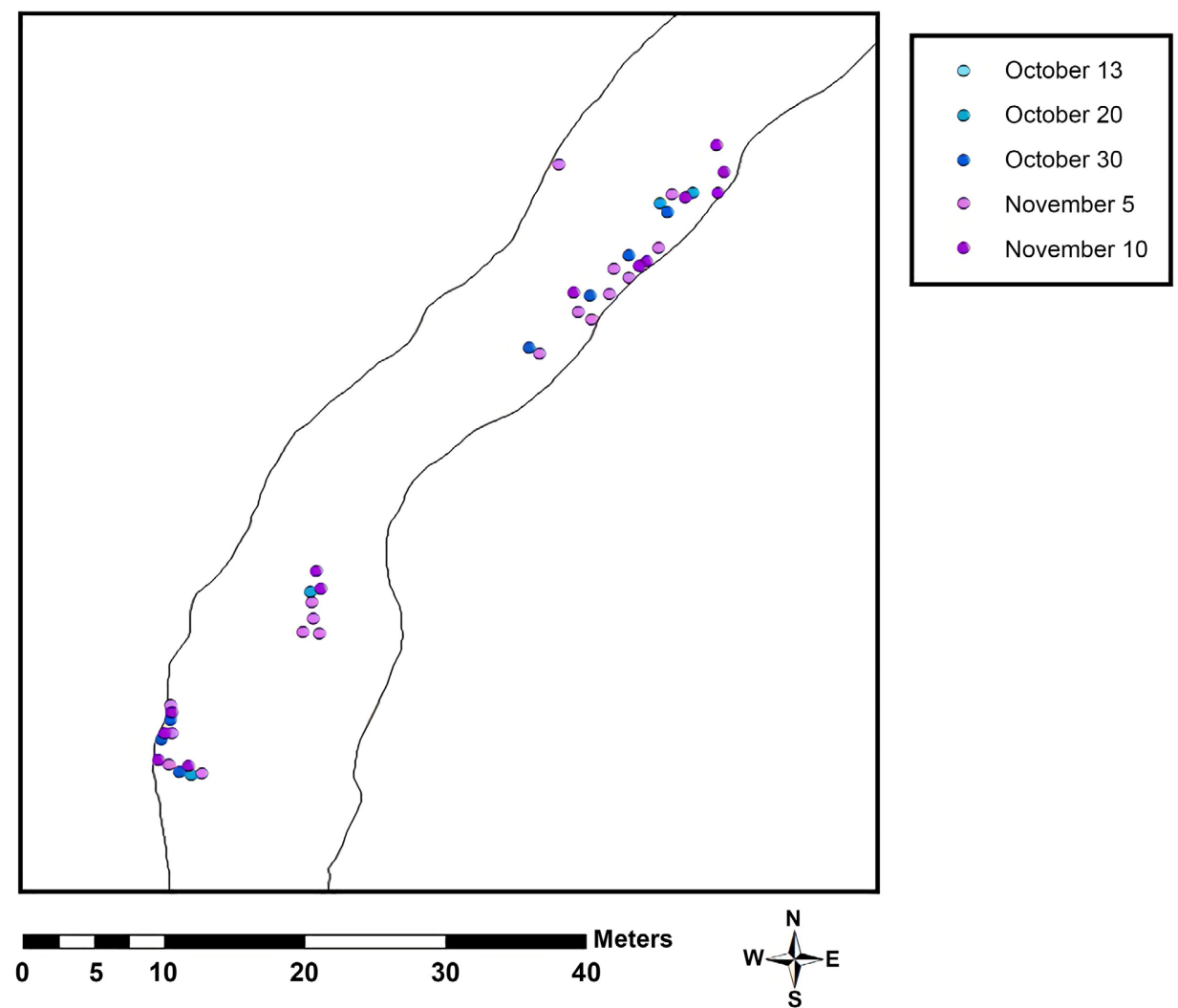

Figure 14. Weekly additions of redds in one concentrated area in section 4 .

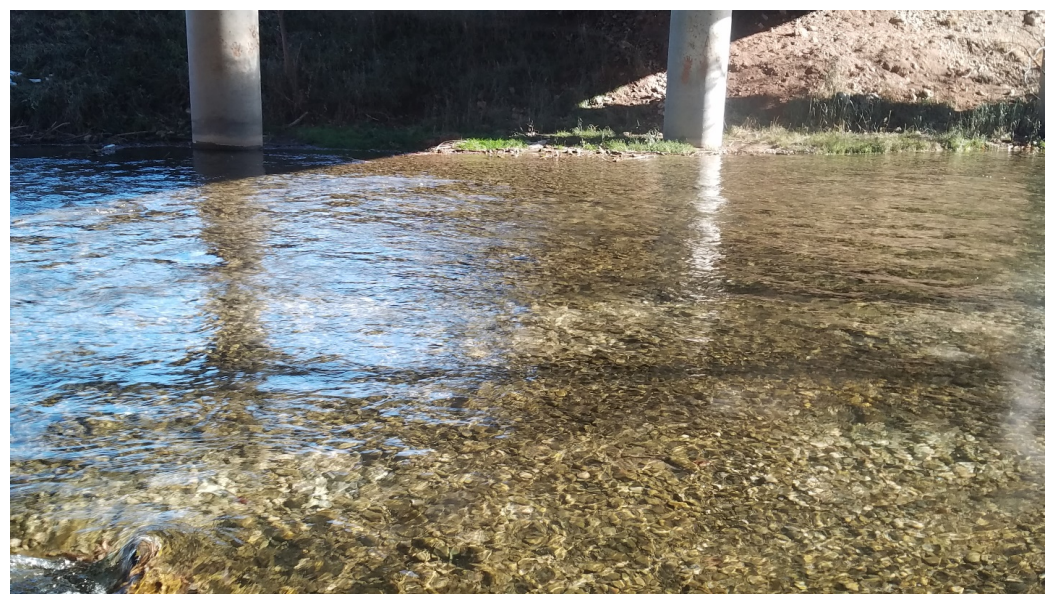

Figure 15. Photo of redds under highway 14 bridge.

\subsection{Redd Density}

At $91 \mathrm{redds} / \mathrm{km}$, the redd density observed in this study is similar to the 84 redds/km reported by Martling et al. [9] for an upstream section of Spearfish Creek. In other streams in the Black Hills, redd densities of 106 redds $/ \mathrm{km}, 43$ redds $/ \mathrm{km}$, and approximately 5 redds/km were reported for Rapid Creek, Box Elder Creek, and Crow Creek, respectively [7] [8]. In locations outside of the Black Hills, redd densities of 73 redds/ $\mathrm{km}$ were reported in Scotland [32], 36 redds $/ \mathrm{km}$ in Spain [33], and $10 \mathrm{redds} / \mathrm{km}$ in Canada [27]. Spearfish Creek may 
have high redd densities because of the high-water quality, good spawning substrate, and lack of sedimentation, as opposed to the lower densities of redds observed in the more heavily-sedimented Crow Creek and Box Elder Creek [7] [8] [9] [34].

\subsection{Superimposition}

Redd superimposition, when a female trout uses a previously excavated redd, was observed in this study [35] [36] [37]. Martling et al. [9] did not report redd superimposition in a more upstream location on Spearfish Creek but stated that redds were in very close proximity to one another. Redd superimposition has only been reported in the Black Hills where both brown trout and brook trout coexist at relatively high numbers [8]. Only intra-specific superimposition occurred in this study, however. Brook trout are only rarely observed in the section of Spearfish Creek in Spearfish, and only brown trout were observed spawning. Superimposition of salmonid redds has been observed in other locations outside of the Black Hills and may be due to brown trout altered creek substrates, homing behavior, or other non-habitat related reasons [33] [37] [38].

\subsection{Limitations}

Because this study was conducted for only one spawning season on one specific $1.6 \mathrm{~km}$ reach of Spearfish Creek, the results may not be applicable to other reaches of Spearfish Creek or other reaches of the $1287 \mathrm{~km}$ of streams in the Black Hills [2]. The relative inexperience of the redd observer may have also impacted the results [25]. Just because a redd is observed does not necessarily mean that eggs were deposited or that reproduction was successful. However, despite these limitations, the similarity of the results of this study to those reported for an upstream location of Spearfish Creek [9] provides some assurance that the results are valid.

\subsection{Implications}

Salmonid populations can be estimated using redd counts [13] [14] [15] [16] [17] [39]. Redd surveys are also much less expensive than using stream electrofishing for population monitoring [13] [14] [15] [16] [17]. Thus, the use of brown trout redd surveys could be a feasible alternative to electrofishing Spearfish Creek on a regular basis as is currently done. In addition, because redd monitoring can assess environmental changes [18], this initial study can be used as a baseline for comparison to future changes in this specific section of Spearfish Creek due to urbanization [26] [30] [31] [40].

\subsection{Conclusion}

This study showed that redds in this section of Spearfish Creek are being made from mid-October through mid-November, which is consistent with Martling et al. [9]. With continuation of these studies throughout the Black Hills, future habitat projects can be created to potentially improve spawning habitat for salmo- 
nid fish, and increase angler satisfaction.

\section{Acknowledgements}

We would like to thank Shaylee Martling, Nathan Huysman, and Jeff Stevens for their assistance with this study.

\section{Conflicts of Interest}

The authors declare no conflicts of interest regarding the publication of this paper.

\section{References}

[1] Barnes, M.E. (2007) Fish Hatcheries and Stocking Practices: Past and Present. In: Berry, C.R., Higgins, K.F., Willis, D.W. and Chipps, S.R., Eds., History of Fisheries and Fishing in South Dakota, South Dakota Department of Game, Fish and Parks, Pierre, 267-294.

[2] Erickson, J.W. and Koth, R. (2000) Black Hills of South Dakota Fishing Guide. South Dakota Department of Game, Fish and Parks, Pierre.

[3] James, D.A. (2011) The Influence of Didymosphenia geminate on Fisheries Resources in the Black Hills of South Dakota. Ph.D. Dissertation, South Dakota State University, Brookings.

[4] Kientz, J.L. (2016) Survival, Abundance, and Relative Predation of Wild Rainbow Trout in the Deerfield Reservoir System, South Dakota. M.S. Thesis, South Dakota State University, Brookings.

[5] Witzel, L.D. and Maccrimmon, H.R. (1983) Redd-Site Selection by Brook Trout and Brown Trout in Southwestern Ontario Streams. Transactions of the American Fisheries Society, 112, 760-771. https://doi.org/10.1577/1548-8659(1983)112<760:RSBBTA >2.0.CO;2

[6] Wydowksi, R.S. and Whitney, R.R. (2003) Inland Fishes of Washington. 2nd Edition, University of Washington Press, Seattle.

[7] Ketelsen, B., Simpson, G. and Barnes, M.E. (2017) Trout Redd Locations in Two Streams in the Black Hills, South Dakota, USA. Natural Resources, 8, 91-102. https://doi.org/10.4236/nr.2017.82007

[8] Blaine, T., Simpson, G. and Barnes, M.E. (2018) A Survey of Brown Trout Redd Locations in Crow Creek, Lawrence County, South Dakota, USA. International Journal of Pure and Applied Zoology, 6, 9-14.

[9] Martling, S., Simpson, G., Kientz, J.L., Rosburg, A.J. and Barnes, M.E. (2020) Brown Trout Spawn Timing, Redd Locations, and Stream Characteristics in Spearfish Creek within Spearfish, South Dakota, USA. Open Journal of Ecology, 10, 177-188. https://doi.org/10.4236/oje.2020.104012

[10] Helfman, G.S., Collette, B.B. and Facey, D.E. (2003) The Diversity of Fishes. Blackwell Science, Malden.

[11] Knapp, R.A. and Preisler, H.K. (1999) Is It Possible to Predict Habitat Use by Spawning Salmonids? A Test Using California Golden Trout (Oncorhynchus mykiss aguabonita). Canadian Journal of Fisheries and Aquatic Sciences, 56, 1576-1584. https://doi.org/10.1139/f99-081

[12] Grost, R.T., Hubert, W.A. and Wesche, T.A. (1990) Redd Site Selection by Brown Trout in Douglas Creek, Wyoming. Journal of Freshwater Ecology, 5, 365-371. https://doi.org/10.1080/02705060.1990.9665249 
[13] Meffe, G.K. (1986) Conservation Genetics and the Management of Endangered Fishes. Fisheries, 11, 14-23. https://doi.org/10.1577/1548-8446(1986)011<0014:CGATMO>2.0.CO;2

[14] Konkel, G.W. and McIntyre, J.D. (1987) Trends in Spawning Populations of Pacific Anadromous Salmonids. U.S. Fish and Wildlife Service Technical Report 9.

[15] Pratt, K.L. (1992) A Review of Bull Trout Life History. In: Howell, P.J. and Buchanan, D.V., Eds., Proceedings of the Gearhart Mountain Bull Trout Workshop, American Fisheries Society, Oregon Chapter, Corvallis, 5-9.

[16] Weaver, T.M. (1992) Coal Creek Fisheries Monitoring Study Number X and ForestWide Fisheries Monitoring 1990. Montana Department of Fish, Wildlife and Parks, Special Projects, Kalispell. https://doi.org/10.5962/bhl.title.130164

[17] Rieman, B.E. and McIntyre, J.D. (1996) Spatial and Temporal Variability in Bull Trout Redd Counts. North American Journal of Fisheries Management, 16, 132-141. https://doi.org/10.1577/1548-8675(1996)016<0132:SATVIB >2.3.CO;2

[18] Warren, D.R., Robinson, J.M., Josephson, D.C., Sheldon, D.R. and Kraft, C.E. (2012) Elevated Summer Temperatures Delay Spawning and Reduce Redd Construction for Resident Brook Trout (Salvelinus fontinalis). Global Change Biology, 18, 1804-1811. https://doi.org/10.1111/j.1365-2486.2012.02670.x

[19] Stetler, L.D. and Sieverding, H.L. (2001) Environmental Controls on Fish Spawning Habitat in Spearfish Creek, Black Hills, SD. Proceedings of the South Dakota Academy of Science, 80, 109-117.

[20] World Population Review (2019) Spearfish South Dakota Population 2019. http://worldpopulationreview.com/us-cities/spearfish-sd-population

[21] South Dakota Department of Environmental and Natural Resources (DENR) (2019) Water Rights. https://denr.sd.gov/des/wr/dbwr.aspx

[22] South Dakota Department of Environmental and Natural Resources (DENR) (2019) City of Spearfish 401 Water Quality Certification-Issued. https://denr.sd.gov/des/sw/PNSpearfish401cert.aspx\#

[23] United States Gelogical Service (2021) Spearfish Creek at Spearfish Gauging Station. https://waterdata.usgs.gov/monitoring-location/06431500/\#parameterCode $=00060$ \&startDT $=2020-10-13 \&$ endDT $=2020-11-17$

[24] Bucholz, M.N. and Wilhite, J.W. (2010) Statewide Fisheries Survey, 2009 Survey of Public Waters Part 1/Streams. South Dakota Department of Game, Fish and Parks, Wildlife Division Report 10-09, Pierre.

[25] Gallagher, S.P., Hahn, P.K.J. and Johnson, D.H. (2007) Redd Counts. In: Johson, D.H., Shrier B.M., ONeal, J.S., Knutzen, J.A., Augerot, X., ONeil, T.A. and Pearsons, T.N., Eds., Salmonid Field Protocols Handbook. Techniques for Assessing Status and Trends in Salmon and Trout Populations, American Fisheries Society, Bethesda, 197-234.

[26] Riedl, C. and Peter, A. (2013) Timing of Brown Trout Spawning in Alpine Rivers with Special Consideration of Egg Burial Depth. Ecology of Freshwater Fish, 22, 384-397. https://doi.org/10.1111/eff.12033

[27] Zimmer, M.P. and Power, M. (2006) Brown Trout Spawning Habitat Selection Preferences and Redd Characteristics in the Credit River, Ontario. Journal of Fish Biology, 68, 1333-1346. https://doi.org/10.1111/j.0022-1112.2006.00995.x

[28] Alp, A., Kara, C. and Buyukcapar, H.M. (2003) Reproductive Biology of Brown Trout, Salmo trutta macrostigma Dumeril 1858, in a Tributary of the Ceyhan River which Flows into the Eastern Mediterranean Sea. Journal of Applied Ichthyology, 19, 346-351. https://doi.org/10.1111/j.1439-0426.2003.00455.x 
[29] Rubin, J.F., Glimsater, C. and Jarvis, T. (2005) Spawning Characteristics of the Anadromous Brown Trout in a Small Swedish Stream. Journal of Fish Biology, 66, $107-$ 121. https://doi.org/10.1111/j.0022-1112.2005.00586.x

[30] Webb, J.H. and McLay, H.A. (1996) Variation in the Time of Spawning of Atlantic Salmon (Salmo salar) and its Relationship to Temperature in the Aberdeenshire Dee, Scotland. Canadian Journal of Fisheries and Aquatic Sciences, 53, 2739-2744. https://doi.org/10.1139/f96-240

[31] Makrov, A.A., Artamonova, V.S., Sumarokov, V.S., Pashkov, A.N., Reshetnikov, S.I., Ganchenko, M.V. and Kulyan, S.A. (2011) Variation in the Timing of Spawning of the Black Sea Brown Trout Salmo trutta labrax Pallas under Artificial and Natural Conditions. Biology Bulletin, 38, 138-145. https://doi.org/10.1134/S1062359011020075

[32] Youngson, A.F, Piertney, S.B., Thorley, J.L., Malcolm, I.A. and Soulsby, C. (2011) Spatial Association of Nest Construction by Brown Trout Salmo trutta. Journal of Fish Biology, 78, 713-725. https://doi.org/10.1111/j.1095-8649.2010.02883.x

[33] Gortázar, J., Alonso, C. and García de Jalón, E. (2012) Brown Trout Redd Superimposition in Relation to Spawning Habitat Availability. Ecology of Freshwater Fish, 21, 283-292. https://doi.org/10.1111/j.1600-0633.2011.00546.x

[34] Wohl, N.E. and Carline, R.F. (1996) Relations among Riparian Grazing, Sediment Loads, Macroinvertebrates, and Fishes in Three Central Pennsylvania Streams. Canadian Journal of Fisheries and Aquatic Sciences, 53, 260-266.

https://doi.org/10.1139/f95-264

[35] Gallagher, S.P. and Gallagher, C.M. (2005) Discrimination of Chinook Salmon, Coho Salmon, and Steelhead Redds and Evaluation of the Use of Redd Data for Estimating Escapement in Several Unregulated Streams in Northern California. North American Journal of Fisheries Management, 25, 284-300. https://doi.org/10.1577/M04-016.1

[36] Reiser, D.W. and Wesche, T.A. (1977) Determination of Physical and Hydraulic Preferences of Brown and Brook Trout in the Selection of Spawning Locations. Water Resources Series No. 64, Water Resources Research Institute, University of Wyoming, Laramie.

[37] Essington, T.E., Sorensen, P.W. and Paron, P.G. (1998) High Rate of Redd Superimposition by Brook Trout (Salvelinus fontinalis) and Brown Trout (Salmo trutta) in a Minnesota Stream Cannot Be Explained by Habitat Availability Alone. Canadian Journal of Fisheries and Aquatic Sciences, 55, 2310-2316. https://doi.org/10.1139/f98-109

[38] Frank, B.M., Gimenez, O. and Baret, P.V. (2012) Assessing Brown Trout (Salmo trutta) Spawning Movements with Multistate Capture-Recapture Models: A Case Study in a Fully Controlled Belgian Brook. Canadian Journal of Fisheries and Aquatic Sciences, 69, 1091-1104. https://doi.org/10.1139/f2012-041

[39] Elliot, J.M. and Hurley, M.A. (1998) Population Regulation in Adult, But Not Juvenile, Resident Trout (Salmo trutta) in a Lake District Stream. Journal of Animal Ecology, 67, 280-286. https://doi.org/10.1046/j.1365-2656.1998.00185.x

[40] Soulsby, C., Youngson, A.F., Moir, H.J. and Malcolm, I.A. (2001) Fine Sediment Influence on Salmonid Spawning Habitat in a Lowland Agricultural Stream: A Preliminary Assessment. Science of the Total Environment, 265, 295-307. https://doi.org/10.1016/S0048-9697(00)00672-0 